\title{
Antimicrobial polycarbonates for biomedical applications
}

\author{
Sergiy P Rogalsky ${ }^{1 *}$, Olena V Moshynets ${ }^{2}$, Lyudmila G Lyoshina', Oksana P Tarasyuk \\ From EPMA-World Congress 2013 \\ Brussels, Belgium. 20-21 September 2013
}

\section{Background}

Polycarbonate $(\mathrm{PC})$ is one of the most widely used engineering polymers due to its unusual combination of optical clarity, heat resistance, high impact strength and dimensional stability over wide thermal range [1]. Low water absorption, ease of sterilization and biocompatibility of PC have led to its use in a wide range of medical equipment, including critical medical devices [2]. The prevention of biofilm formation on the internal medical devices is of great importance since it can initiate a degradation process of the material, as well as cause infections and health related problems [3]. In order to obtain antimicrobial properties, polymers are usually compounded with organic or inorganic biocides [4,5]. However, the use of organic biocides as additives for PC is significantly limited due to their insufficient thermal stability in the temperature range used for PC processing $\left(300-320^{\circ} \mathrm{C}\right)$.

\section{The aim}

of research was to develop novel low toxic biocides for PC having sufficient thermal stability for the joint melt processing with $\mathrm{PC}$ resin.

\section{Materials and methods}

Two kinds of potential antimicrobial additives for PC have been synthesized: imidazolium and guanidinium ionenes, as well as imidazolium based ionic liquids. PC films containing from 1 to $10 \mathrm{wt} \%$ of biocides were prepared by solvent casting or by compression molding methods. The thermal stability of novel biocides as well as modified PC was investigated by using thermogravimetric analysis (TGA). Antimicrobial testing of PC composites were performed using a model bacteria Pseudomonas fluorescens

\footnotetext{
* Correspondence: sergey.rogalsky@gmail.com

${ }^{1}$ Institute of Bioorganic Chemistry and Petrochemistry of NAS of Ukraine, Kyiv, Ukraine

Full list of author information is available at the end of the article
}

SBW25 with a help of classical microbiological methods for bacterial suspension as well as a live-dead assay for biofilms [6].

\section{Results}

According to TGA data, the thermal stability of PC samples containing biocidal additives was found to be in the range of $350-425{ }^{\circ} \mathrm{C}$ that is quite sufficient for their melt processing. The results of microbiological investigations showed pronounced antimicrobial efficacy of PC films containing $3-4 \mathrm{wt} \%$ of ionic liquids or $5-8 \mathrm{wt} \%$ of ionene polymers.

\section{Conclusions}

Imidazolium ionic liquids and ionene polymers are promising antimicrobial additives for PC resins since they combine high thermal stability, low toxicity and broad spectrum of antimicrobial activity.

\section{Outlook and expert recommendations}

According to the obtained results we recommend to expand the application of polimers to design polycarbonate based medical devices for prevention of postoperative infectious complications in orthopedics after performing relevant biosafety and preclinical tests.

\footnotetext{
Authors' details

${ }^{1}$ Institute of Bioorganic Chemistry and Petrochemistry of NAS of Ukraine, Kyiv, Ukraine. ${ }^{2}$ Institute of Molecular Biology and Genetics of NAS of Ukraine, Kyiv, Ukraine.

Published: 11 February 2014

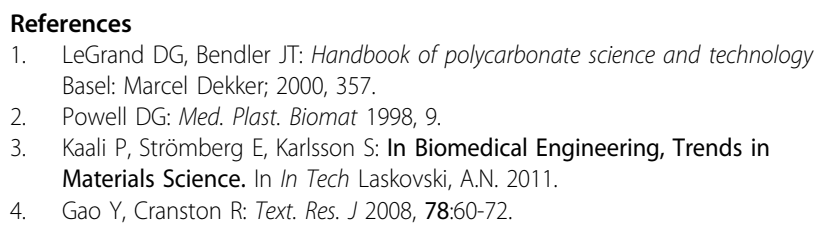

\section{References}

LeGrand DG, Bendler JT: Handbook of polycarbonate science and technology Basel: Marcel Dekker; 2000, 357

2. Powell DG: Med. Plast. Biomat 1998, 9.

Materials Science. In In Tech Laskovski, A.N. 2011.

(c) 2014 Rogalsky et al; licensee BioMed Central Ltd. This is an Open Access article distributed under the terms of the Creative Commons Attribution License (http://creativecommons.org/licenses/by/2.0), which permits unrestricted use, distribution, and reproduction in any medium, provided the original work is properly cited. The Creative Commons Public Domain Dedication waiver (http://creativecommons.org/publicdomain/zero/1.0/) applies to the data made available in this article, unless otherwise stated. 
doi:10.1186/1878-5085-5-S1-A133

Cite this article as: Rogalsky et al: Antimicrobial polycarbonates for

biomedical applications. EPMA Journal 2014 5(Suppl 1):A133.

Submit your next manuscript to BioMed Central and take full advantage of:

- Convenient online submission

- Thorough peer review

- No space constraints or color figure charges

- Immediate publication on acceptance

- Inclusion in PubMed, CAS, Scopus and Google Scholar

- Research which is freely available for redistribution 